\title{
Lithium in Public Drinking Water and Suicide Mortality in Portugal: Initial Approach
}

\section{Lítio nas Águas de Consumo Públicas e Mortalidade por Suicídio em Portugal: Primeira Abordagem}

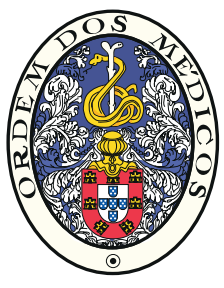

\author{
Pedro OLIVEIRA $\triangle^{1,2}$, Joana ZAGALO ${ }^{3}$, Nuno MADEIRA ${ }^{1,2}$, Orquídia NEVES ${ }^{4}$ \\ Acta Med Port 2019 Jan;32(1):47-52 • https://doi.org/10.20344/amp.10744
}

\section{ABSTRACT}

Introduction: Lithium can be found naturally in drinking water. There is some evidence that natural levels of lithium in drinking water may have a protective effect on suicide mortality. The aim of this study is to evaluate if higher natural concentrations of lithium in public drinking water are associated with lower local rates of suicide in Portugal.

Material and Methods: Suicide standardized mortality ratios at 54 Portuguese municipalities within the 6-year period from 2011 to 2016 was correlated with lithium concentrations in public drinking water and socioeconomic factors using Pearson's correlation coefficients $(r)$ with one-tailed tests. Multivariate regression models were adjusted for well-known socioeconomic factors known to influence suicide mortality in Portugal (population density, average income per capita, unemployment rates and proportion of Roman Catholics).

Results: The average lithium level, as evidenced by raw values for 54 municipalities, was $10.88 \mu \mathrm{g} / \mathrm{L}$ (standard deviation $=27.18$ ). There was no statistically significant correlation between lithium levels and suicide standardized mortality ratio $(r=0.001, p$-value $=$ 0.996). There was a statistically significant higher suicide standardized mortality ratio for males ( $p$-value $=0.000)$. When analyzed separately for both sexes, no statistically significant correlation between suicide standardized mortality ratio and lithium levels was found (male $r=0.024, p$-value $=0.862$; female $r=0.000, p$-value $=0.999$ ). No association between suicide standardized mortality ratio and socioeconomic factors was found: population density $(r=-0.144, p$-value $=0.300)$, average income per capita $(r=-0.112, p$-value $=0.418)$, unemployment rates $(r=-0.001, p$-value $=0.994)$, and proportion of Roman Catholics $(r=-0.150, p$-value $=0.278)$.

Discussion: Unlike most international studies regarding natural lithium levels and suicide risk, no inverse relation was found in Portugal. Factors such as the country's low suicide rate, confunding suicide risk variables, and unaccounted lithium intake might have influenced these findings.

Conclusions: No association between lithium in public drinking water and suicide rates was found in Portugal.

Keywords: Drinking Water; Lithium; Portugal; Suicide; Water Supply

\section{RESUMO}

Introdução: O lítio faz parte dos constituintes naturais da água potável. Algumas evidências referem que os níveis de lítio presentes na água potável podem ter um efeito protetor na mortalidade por suicídio. O objetivo deste estudo é avaliar se concentrações mais elevadas de lítio nas águas da rede pública estão associadas a menores taxas de suicídio em Portugal.

Material e Métodos: Taxas de mortalidade padronizada por suicídio em 54 municípios portugueses, no período de seis anos de 2011 a 2016, foram correlacionadas com concentrações de lítio em água potável pública e fatores socioeconómicos usando coeficientes de correlação de Pearson ( $r$ ). Foram usados modelos de regressão multivariada para ajustar a relação com factores socioeconómicos tidos como possíveis influenciadores da mortalidade por suicídio em Portugal (densidade populacional, rendimento médio per capita, taxas de desemprego e proporção de católicos).

Resultados: O nível médio de lítio, dos 54 municípios analisados, foi de 10,88 $\mu \mathrm{g} / \mathrm{L}$ (desvio padrão $=27,18$ ). Não se verificou uma correlação estatisticamente significativa entre a taxa de mortalidade padronizada por suicídio e os níveis de lítio $(r=0,001, p$-value $=$ $0,996)$. Apesar de ser ter verificado uma taxa de mortalidade padronizada por suicídio estatisticamente superior no sexo masculino $(p$-value $=0,000)$, quando analisados separadamente ambos os sexos, não foi encontrada correlação estatisticamente significativa entre taxa de mortalidade padronizada por suicídio e níveis de lítio (masculino $r=0,024, p$-value $=0,862$; feminino $r=0,000, p$-value $=0,999)$. Não foi encontrada associação entre taxa de mortalidade padronizada por suicídio e fatores socioeconómicos: densidade populacional $(r=-0,144, p$-value $=0,300)$, índice de poder de compra $(r=-0,112, p$-value $=0,418)$, taxas de desemprego $(r=-0,001$, $p$-value $=0,994)$ e proporção de católicos $(r=-0,150, p$-value $=0,278)$.

Discussão: Ao invés da maioria dos estudos internacionais sobre os níveis naturais de lítio e o risco de suicídio, não se encontrou em Portugal uma associação inversa. Factores como a baixa taxa nacional de suicídio, variáveis confundentes de risco suicida e outras fontes de ingesta de lítio poderão ter influenciado estes achados.

Conclusões: Não se verificou uma associação entre níveis de lítio na água potável e as taxas de suicídio.

Palavras-chave: Abastecimento de Água; Água Potável; Lítio; Portugal; Suicídio

\section{INTRODUCTION}

Suicide is one of the largest health burdens in industrialized nations. ${ }^{1}$ Traditionally, Portugal is touted as a country with low standardized suicide rates, alongside other coun-

tries in Southern Europe, where rates have also been declining - currently at around 7.5 per 100000 inhabitants, in contrast to an European average of 10 per $100000 .^{2}$

\footnotetext{
1. Psychiatry Department. Centro Hospitalar e Universitário de Coimbra. Coimbra. Portugal.

2. Institute of Psychological Medicine. Faculty of Medicine. University of Coimbra. Coimbra. Portugal.

3. Family Health Unit "CelaSaúde". Regional Health Administration of Central Portugal. Coimbra. Portugal.

4. CERENA (Centro de Recursos Naturais e Ambiente) \& DECivil (Department of Civil Engineering, Architecture and Georesources). Instituto Superior Técnico. Universidade de Lisboa. Lisboa. Portugal.

$\square$ Autor correspondente: Pedro Oliveira. pedrosantosoliveira89@gmail.com

Recebido: 01 de maio de 2018 - Aceite: 10 de setembro de 2018 | Copyright @ Ordem dos Médicos 2019
} 
Suicide is considered a multifactorial event caused by a complex interaction between biological, genetic, psychological, social and environmental factors. ${ }^{3}$ The complexity of epidemiology of suicide is amplified by considerable risk variations between nations and within countries. ${ }^{1}$ Several studies from developing and industrialized countries indicate a prevalence of mental disorders in about $90 \%$ of cases of suicide; in particular, individuals with a mood disorder have a suicide risk 10 to 20 times higher than the general population. ${ }^{3}$ Several meta-analyses of clinical trials have found that suicide risk among those with mood disorders is significantly reduced when they are treated with lithium. ${ }^{4}$ It has been proposed that lithium's anti-suicidal properties might be independent from its mood-stabilizing effects. ${ }^{5}$ The recommended serum levels for lithium in bipolar disorder maintenance therapy range between 0.6 and $1.0 \mathrm{mmol} / \mathrm{L}$; nonetheless, the optimal blood level at which lithium exerts its possible suicide preventive effect has not been identified. ${ }^{6}$ As a natural trace element, lithium is mobilized by rock weathering to soils and ground or surface water. In some regions drinking water sources may present high concentrations of lithium, as the Lluta river $(0.33 \mathrm{mmol} / \mathrm{L})$ in Northern Chile, reflecting a natural daily intake of lithium of up to $1.5 \mathrm{mmol} / \mathrm{day} .{ }^{7,8}$ Although such daily doses of lithium are considerably lower than those used therapeutically, it is unknown to what extent the intake of natural lithium might influence mental health or suicide mortality. ${ }^{8}$ Although natural lithium intake doses are relatively low, there is growing evidence that even very low lithium levels induced by routine consumption of lithium from public drinking water may have anti-suicidal effects, both in patients with mood disorders and in general population. ${ }^{9}$ However, most studies have been criticized for omitting socioeconomic confounders such as poverty and economic issues. ${ }^{8}$ Several factors such sex, age, population density, average income per capita, unemployment rates and proportion of Roman Catholics were recently shown to influence suicide mortality in Portugal. ${ }^{10}$

To address the hypothesis that lithium levels and public drinking water are inversely associated with suicide mortality, we evaluated this correlation in Portugal while adjusting the data for relevant regional socioeconomic conditions.

\section{MATERIAL AND METHODS}

An empirical analysis was conducted in Portugal using an ecological study design. Portugal is divided into 308 municipalities: 278 located in continental territory, 11 in the archipelago of Madeira and 19 in the archipelago of Azores. For this study, we evaluated 54 semi-randomly selected municipalities, considering the need for homogeneous geographic distribution, covering all regions of the country. The Portuguese National Statistics Institute (INE) was the source of data regarding mortality, population and socioeconomic conditions (www.ine.pt). INE provided the official Portuguese mortality database for suicides according to International Classification of Diseases $10^{\text {th }}$
Revision (ICD-10) ${ }^{11}$ codes X60 - X84 - in 19 age groups and both genders for every municipality and for each year in the period 2011 - 2016. Other data of interest such as population density, average income per capita, unemployment rates and proportion of Roman Catholics were also obtained using INE database. As suicide is a rare event, the annual data were pooled over time to reduce the random fluctuations of suicides within a municipality. By taking the difference in gender and age distribution of individual municipality populations into account, the standardized mortality ratio (SMR) of suicide was calculated for each municipality taking the age composition of general Portuguese population as standard.

Lithium levels were obtained from public drinking water samples that were collected from private houses in Portugal. Samples are representative of the water that is consumed by the Portuguese population for drinking or cooking every day. Public drinking water may be derived from groundwater or from surface water (e.g. lakes, rivers, artificial reservoirs) and could be mixed in the distribution system. Lithium was analyzed by inductively coupled plasma mass spectrometry (ICP-MS), with a detection limit of $1 \mu \mathrm{g} / \mathrm{L}$, at a certified laboratory (Actlabs, Canada), after acidifying water $\left(\mathrm{HNO}_{3}\right.$ until $\mathrm{pH}<2$ ) and without sample filtration after collection. The sample data were collected between 2011 and 2014 . In total, 54 water supplies from 54 municipalities were analyzed. Subthreshold values $(<1 \mu \mathrm{g} / \mathrm{L})$ were found in eight samples.

We used Pearson's correlation coefficients $(r)$ with one tailed tests to study the correlation between local suicide SMR and lithium concentrations, population density, average income per capita, unemployment rates and proportion of Roman Catholics. The same was done between SMR and because of greater differences in population size across the 54 municipalities, weighted least squared (WLS) regression analyses adjusted for the size of the population per district were employed to test for the robustness of univariate and multivariate statistics. Multivariate regression models incorporated those covariates that were significantly correlated with SMR for suicide (population density, average income per capita, unemployment rates and proportion of Roman Catholics) in correlation tests. Data analysis was performed on SPSS 23.0 for Windows. The level of significance considered was $5 \%(p$ - value $<0.05)$.

\section{RESULTS}

In 2011 - 2016, total suicide SMR mean was 1.19, standard deviation $(S D)=0.97$; males $1.74(S D=1.05)$ and females $0.55(\mathrm{SD}=0.63)$. The lowest suicide SMR was found in Santa Cruz das Flores (Azores archipelago) and Porto Santo (Madeira archipelago), both without suicide deaths. The highest suicide SMR in both sexes was found in Fronteira (Alentejo) with total SMR of $7.12 ; 5.94$ for males and 4.67 for females (Fig. 1A). There was a higher suicide SMR for males. This difference was statistically significant $(p-$ value $=0.000)$.

The average lithium level, as evidenced by raw values 
A

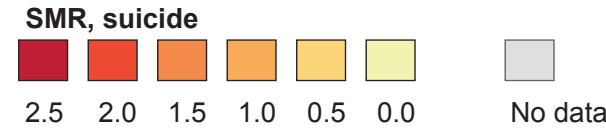

8
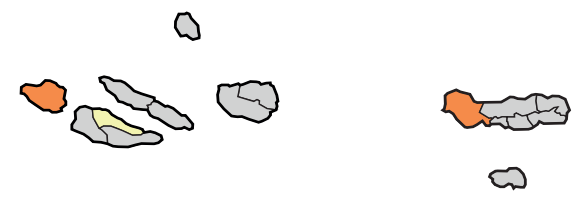

Azores archipelago
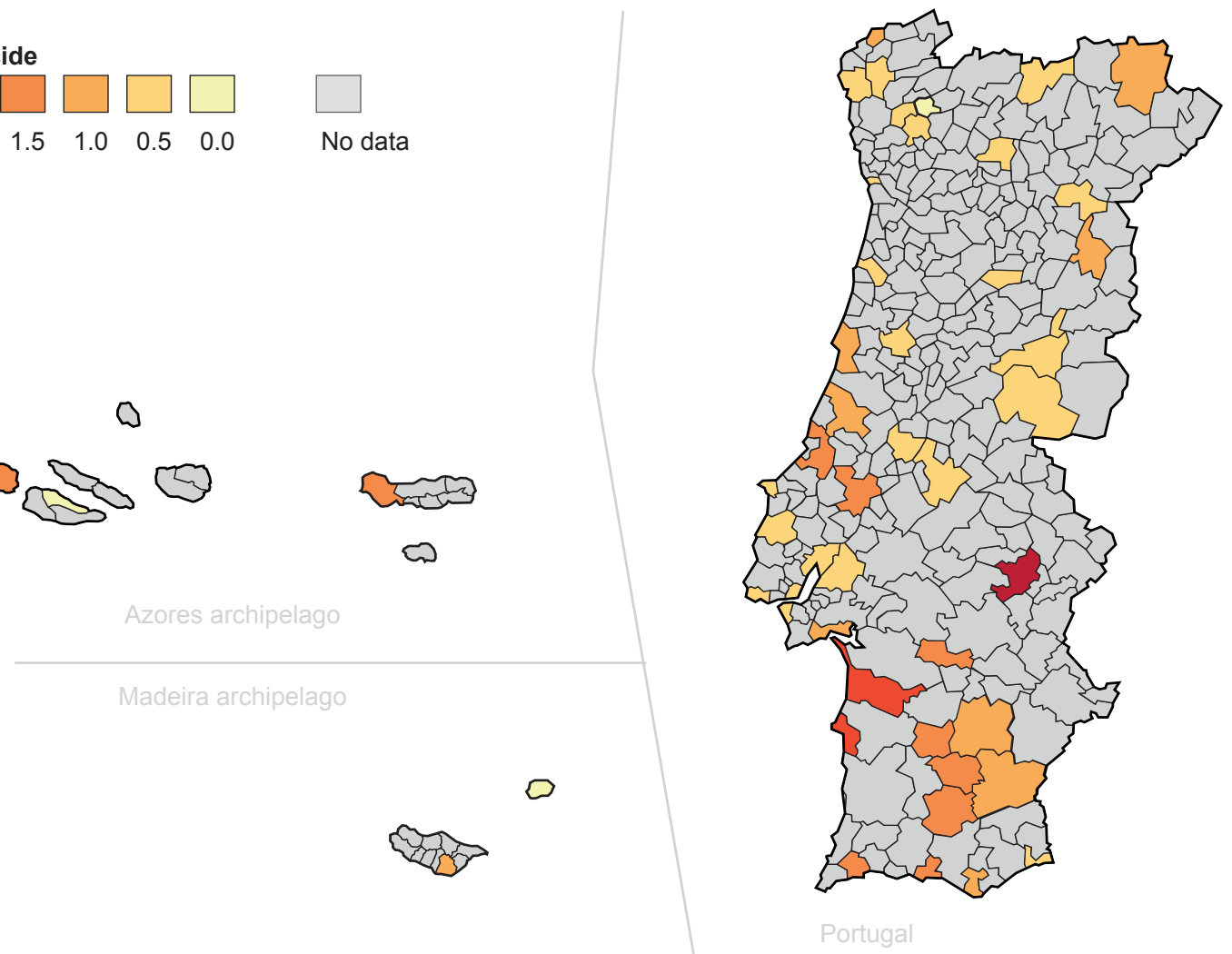

B
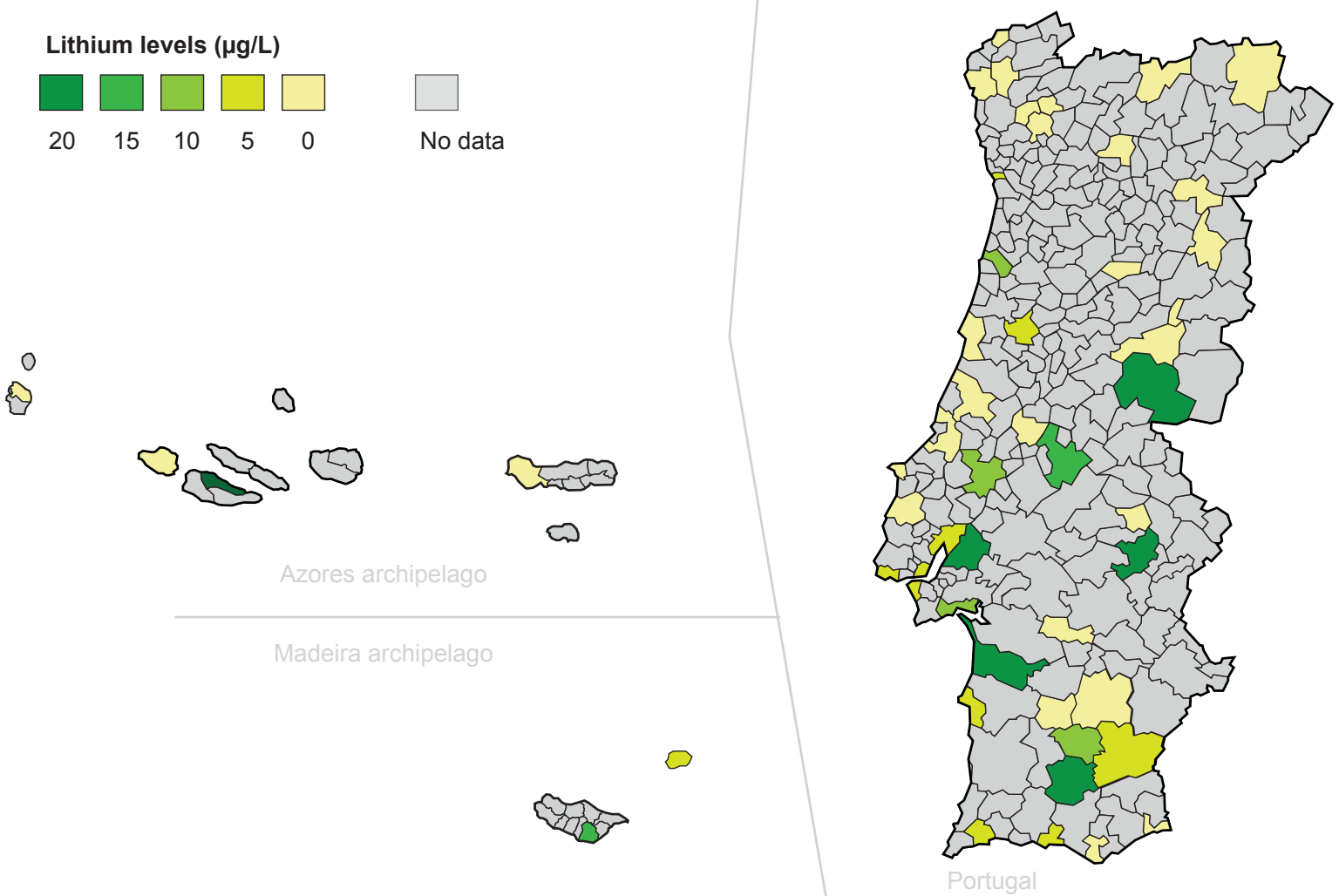

Figure 1 - Spatial distribution of: (A) standardized mortality ratio (SMR) for suicide: (B) lithium levels in public drinking water 


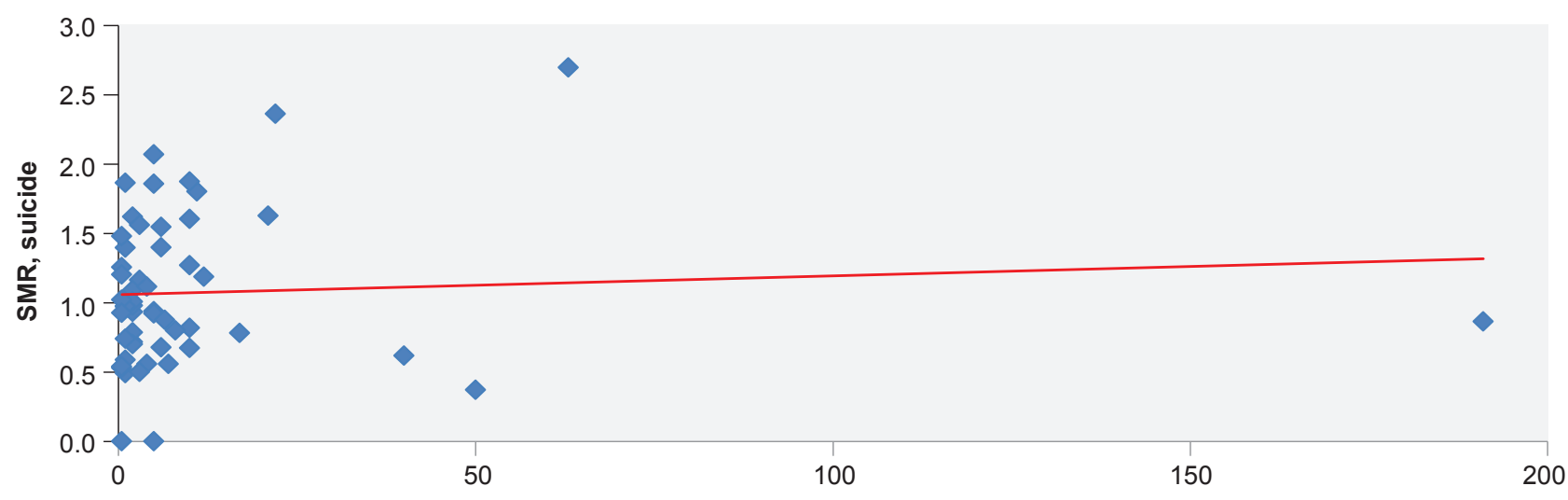

Lithium levels $(\mu \mathrm{g} / \mathrm{L})$

Figure 2 - Lithium levels in public drinking water and standardizes mortality ratios (SMR) for suicide from 2011 to 2016

for 54 municipalities, was $10.88 \mu \mathrm{g} / \mathrm{L}(\mathrm{SD}=27.18)$. The highest level was found in Castelo $\operatorname{Branco}^{20}(191 \mu \mathrm{g} / \mathrm{L})$ (Fig. 1B). There was no statistically significant correlation between lithium levels and suicide SMR (Fig. 2). When SMR was analyzed separately for both sexes, no statistically significant correlation was found (Male $r=0.024, p$-value $=$ 0.862; Female $r=0.000, p$-value $=0.999$ )

The average population density was 476.2 per $\mathrm{km}^{2}$ (SD $=1188.80)$. The highest population density was found in Lisbon (the capital of Portugal) of 6446.2 per $\mathrm{km}^{2}$ and the lowest was found in Mértola (5.6 per $\mathrm{km}^{2}$ ). No statistically significant correlation was found between suicide SMR and population density (Table 1 ).

The average relative income per capita found in the analyzed municipalities was lower $(96.42 \%$; SD $=24.81$ ) than the national average of the total income per capita. No statistically significant correlation between suicide SMR and income was identified (Table 1).

The average unemployment rate was $12.69 \%$ (SD = $2.83), 11.96 \%(S D=3.23)$ for males and $13.60 \%$ (SD = 3.19) for females. The highest unemployment rate was $20.9 \%$ in Ponte de Sor (Alentejo) and the lowest was $7.3 \%$ in São Roque (Azores). There was no statistically significant correlation between suicide SMR and unemployment rates (Table 1).

The average proportion of Roman Catholics was $80.3 \%$ $(S D=9.8)$. The highest proportion of Roman Catholics was found in Póvoa do Lanhoso (94.7\%) and the lowest in Lagos (58.7\%). There was also no statistically significant

Table 1 - Correlation between municipality characteristics and standardized mortality ratios (SMR)

\begin{tabular}{lcc}
\hline & \multicolumn{2}{c}{ Suicide SMR } \\
& $r$ & $p$-value \\
\hline Lithium level, mean (ug/L) & 0.001 & 0.996 \\
Purchasing power index, \% & -0.112 & 0.418 \\
Population density (per $\mathrm{km}^{2}$ ) & -0.144 & 0.300 \\
Unemployment rate, \% & -0.001 & 0.994 \\
Proportion of Roman Catholics, \% & -0.150 & 0.278 \\
\hline
\end{tabular}

correlation between suicide SMR and the proportion of Roman Catholics (Table 1).

In the final weighted (WLS) multivariate model, no statistically significant differences between lithium levels and suicide SMR remained.

\section{DISCUSSION}

This is the first study in Portugal (Europe's largest producer of lithium) investigating the association between natural lithium levels in public drinking water and suicide rates. We evaluated whether higher natural lithium levels in the public drinking water were associated with lower local suicide rates in 54 semi-randomly selected Portuguese municipalities. Overall, we found no association between public drinking water lithium levels and mortality from suicide.

The natural lithium levels in drinking water have correlated inversely with suicide risk in most,,8,12-17 but not all studies regarding the relationship between drinking water lithium levels and suicide rates ${ }^{1,6,18}$ Most of these studies did not consider variables associated with variations in suicide rates such as population density, average income per capita, unemployment rates and religiousness; an apparently negative correlation might have been interfered by these important biases.

However, we hypothesize some explanations for this apparent lack of correlation between lithium levels in drinking water and suicide SMR. First, Portugal has one of the lowest suicide rates; many other studies analyzed countries with substantial higher suicide ratios. In such populations, the impact of lithium could be more effective given lithium's anti-suicidal properties could only emerge in individuals with mental disorders and with higher risk factors for suicide. ${ }^{4}$ Second, although we have taken into account variables such as the unemployment rate and income per capita, such variables could have varying contributions in different countries. Portugal has one of the highest unemployment rates and one of the lowest incomes per capita in comparison with other studied countries. It is estimated that these factors will have a greater relative 
interference in suicide rates, reducing the possible influence of lithium levels in drinking water. ${ }^{10}$ In addition, Portugal has recently emerged from one of the greatest contemporary economic and social crisis, a factor influencing suicide rates as demonstrated by Santana et al. ${ }^{10}$ Third, public drinking water may constitute a small fraction of lithium intake. Portugal is also a country with high bottled water and vegetable consumption. ${ }^{19}$ In 2014 , the average consumption of bottled water per inhabitant was $112 \mathrm{~L}$, which is one of the highest among European countries. ${ }^{19}$ There are no drinking water standards for lithium in bottled water in the European Union and there may be significant differences between different types of water. In Portuguese natural mineral and spring bottled waters lithium concentration ranges from $<1$ up to $318444 \mathrm{mmol} / \mathrm{L} .{ }^{20}$ Vegetables and grains are another important dietary source of lithium and in some regions may account for two-thirds of lithium intake. ${ }^{21}$

The physiological basis for lithium's anti-suicidal effects, even at plasma levels usually considered as therapeutic, remains largely unknown. From a clinical perspective, it has been hypothesized that lithium may exert its anti-suicidal effects by reducing relapses of mood disorders. ${ }^{3}$ From a behavioral point of view, the anti-suicidal effect of lithium might be related to its anti-aggressive effects, which have been shown in various species, populations and settings. ${ }^{5}$ Neurobiological mechanisms that may be involved in the anti-suicidal effects of lithium include decreased impulsivity and hostile or aggressive behavior. Such an effect may be mediated by enhanced functioning of the central serotoninergic system. ${ }^{3}$ Several recent studies suggest that lithium also has stimulating effects on neurogenesis ${ }^{22}$ which might relate with its clinical effects.

Although national suicide prevention programs are being increasingly implemented in many countries and researchers keep seeking for effective preventive interventions, it is highly controversial whether adding lithium to public drinking water would reduce suicide mortality, as previously suggested regarding the supplementation of water with fluoride for dental caries prevention. Not only is there no clear evidence of protective effects, nor is the safety of these procedures clear. High lithium concentrations in public drinking water could have deleterious implications for human health. Additional research is needed to understand how lithium in public drinking water could affect thyroid function, pregnant women and fetuses in utero. ${ }^{6,8}$

Our study has some limitations. First, the present findings were derived from 54 municipalities of Portugal (31\% of the general population), and thus only limited generalization is possible. Second, we could not factor other dietary sources of lithium uptake like bottled water, vegetables and grains. ${ }^{16}$ We could not account people's daily job/living area and their tap/bottled water consumption tendencies. On the other hand, lithium rich food may come from the worldwide market and different countries. Third, we did not take in account the accessibility to the health care system of different populations. Finally, the ecological nature of this study cannot determine a causal relationship between lithium levels in public drinking water and suicide mortality.

\section{CONCLUSION}

In conclusion, an association between concentrations of lithium in Portuguese public drinking water and suicide rates remains uncertain. Although this study does not show an association between these two variables, given its various limitations, a cause-effect relationship can be latent. The basis of lithium's positive effect, if it occurs, is unclear, including its apparent ability to reduce suicides in longterm treatment with clinically meaningful doses. Further studies involving increased sampling and considering other interfering factors will be required, as well as a more in-depth study of the mechanisms involved in the possible action of lithium when in naturally occurring amounts. Despite the need for future research, this study adds further insight on the relationship between natural lithium water levels and suicide mortality.

\section{ACKNOWLEDGEMENTS}

We would like to thank Fundação para a Ciência e a Tecnologia for the support through UID/ECI/04028/2013 projects and to the Portuguese National Statistics Institute.

\section{PROTECTION OF HUMANS AND ANIMALS}

The authors declare that the procedures were followed according to the regulations established by the Clinical Research and Ethics Committee and to the Helsinki Declaration of the World Medical Association.

\section{DATA CONFIDENTIALITY}

The authors declare having followed the protocols in use at their working center regarding patients' data publication.

\section{CONFLICTS OF INTEREST}

All authors report no conflict of interest.

\section{FUNDING SOURCES}

The authors were supported by Fundação para a Ciência e a Tecnologia (Project UID/ECI/04028/2013) and the Portuguese National Statistics Institute.

\section{REFERENCES}

1. Helbich M, Leitner M, Kapusta ND. Lithium in drinking water and suicide mortality: Interplay with lithium prescriptions. Br J Psychiatry. 2015;207:64-71.

2. Gusmão R, Quintão $S$. Suicide and death resulting from events of undetermined intent register in Portugal. Revisiting "The truth about suicide", 20 years later. Dir Gen Health J. 2013;1:80-95.

3. Vita A, De Peri L, Sacchetti E. Lithium in drinking water and suicide prevention: a review of the evidence. Int Clin Psychopharmacol. 2015;30:1-5

4. Cipriani A, Hawton K, Stockton S, Geddes JR. Lithium in the prevention 
of suicide in mood disorders: updated systematic review and metaanalysis. BMJ. 2013;346:3646.

5. Müller-Oerlinghausen B, Felber W, Berghöfe A, Lauterbach E, Ahrens B. The impact of lithium long-term medication on suicidal behavior and mortality of bipolar patients. Arch Suicide Res. 2005;9:307-19.

6. Kabacs N, Memon A, Obinwa T, Stochl J, Perez J. Lithium in drinking water and suicide rates across the East of England. $\mathrm{Br} \mathrm{J}$ Psychiatry. 2011;198:406-7.

7. Figueroa L, Barton S, Schull W, Razmilic B, Zumaeta O, Young A, et al. Environmental lithium exposure in the North of Chile-I. Natural water sources. Biol Trace Elem Res. 2012;149:280-90.

8. Kapusta ND, Mossaheb N, Etzersdorfer E, Hlavin G, Thau K, Willeit M, et al. Lithium in drinking water and suicide mortality. $\mathrm{Br} \mathrm{J}$ Psychiatry. 2011;198:346-50.

9. Liaugaudaite V, Mickuviene N, Raskauskiene N, Naginiene R, Sher L. Lithium levels in the public drinking water supply and risk of suicide: a pilot study. J Trace Elem Med Biol. 2017;43:197-201.

10. Santana P, Costa C, Cardoso G, Loureiro A, Ferrão J. Suicide in Portugal: Spatial determinants in a context of economic crisis. Health Place. 2015;35:85-94.

11. World Health Organization. The ICD-10 Classification of Mental and Behavioural Disorders: Clinical Descriptions and Diagnostic Guidelines. Geneve: WHO; 1992.

12. Schrauzer GN, Shrestha KP. Lithium in drinking water and the incidences of crimes, suicides, and arrests related to drug addictions. Biol Trace Elem Res. 1990;25:105-13.

13. Ohgami $\mathrm{H}$, Terao $\mathrm{T}$, Shiotsuki I, Ishii $\mathrm{N}$, Iwata $\mathrm{N}$. Lithium levels in drinking water and risk of suicide1. Br J Psychiatry. 2009;194:464-5.
14. Sugawara N, Yasui-Furukori N, Ishii N, Iwata N, Terao T. Lithium in tap water and suicide mortality in Japan. Int J Environ Res Public Health. 2013;10:6044-8.

15. Giotakos O, Nisianakis P, Tsouvelas G, Giakalou VV. Lithium in the public water supply and suicide mortality in Greece. Biol Trace Elem Res. 2013;156:376-9

16. Blüml V, Regier MD, Hlavin G, Rockett IR, König F, Vyssoki B, et al Lithium in the public water supply and suicide mortality in Texas. J Psychiatr Res. 2013;47:407-11.

17. Helbich $\mathrm{M}$, Blüml V, Leitner M, Kapusta ND. Does altitude moderate the impact of lithium on suicide? A spatial analysis of Austria. Geospat Health. 2013;7:209-18.

18. Pompili M, Vichi M, Dinelli E, Pycha R, Valera P, Albanese S, et al Relationships of local lithium concentrations in drinking water to regional suicide rates in Italy. World J Biol Psychiatry. 2015;16:1-8.

19. Associação Portuguesa dos Industriais de Águas Minerais Naturais e de Nascente - APIAM. 2016. [Accessed 2018 May 01]. Available from: http://www.apiam.pt/conteudo/Mercado/-/10.

20. Neves O, Machete I, Marques JM, Silva JA, Couto FS. Lítio em águas engarrafadas e de abastecimento público portuguesas Lithium in bottled and tap Portuguese waters. Comun Geológicas. 2015;102:103-6.

21. Roos NM De, Katan MB. Serum lithium as a complicance marker for food and supplement intake. Am J Clin Nutr. 2001;73:75-9.

22. Nciri R, Desmoulin F, Allagui MS, Murat JC, Feki AE, Vincent C, et al. Neuroprotective effects of chronic exposure of SH-SY5Y to low lithium concentration involve glycolysis stimulation, extracellular pyruvate accumulation and resistance to oxidative stress. Int $\mathrm{J}$ Neuropsychopharmacol. 2013;16:365-76. 